\title{
Towards Commercial Orientation of Maize Farming In East Nusa Tenggara
}

\author{
Yohanis Ngongo ${ }^{1, *}$, Tony Basuki ${ }^{1}$, Miqdoth S. Abola ${ }^{2}$, Noldy R. E Kotta ${ }^{1}$, Evert Y. Hosang ${ }^{1}$ \\ 1) Researchers at Assessment Institute for Agriculture Technology East Nusa Tenggara (AIAT-ENT) \\ Jl. Timor Raya Km. 32, Kupang, Nusa Tenggara Timur - INDONESIA. \\ 2) Secretary of Provincial Food and Estates Crops Office of ENT; Jl. Polisi Militer No. 07, Kota \\ Kupang, NTT - INDONESIA.
}

\begin{abstract}
Maize constitute dominant food crop in upland semi-arid region of East Nusa Tenggara (ENT) and as a main staple for majority of rural farmers. This paper examines Provincial Government programs to increase maize production and to reform maize production orientation. Data and information being used from the recent program: "Maize Planting, Cattle Harvest (MPCH)". The survey was conducted in all villages in Districts of Timor and Sumba Island as pilot project. The study showed that: 1). Maize farmers keen to change production orientation from subsistence to semi and fully commercial as long as there are surplus production and better access to the market, 2). Average maize productivity of farmers under program $(5-8$ ton/ha) higher than traditional practices $(1-2$ ton/ha), 3$)$. Most farmers under the program have access to have own cattle 1- 2 head/household from surplus production of maize sold with contract price IDR 3,200/kg. This result implies that incorporated farmer into the market from the beginning of the program, technical assistance to apply appropriate innovations, organized farmers groups to enhance business scale and government support to minimize production cost lead farmers to adopt new innovation, increase maize production and change maize production orientation (commercial).
\end{abstract}

\section{Introduction}

Maize has been planted for the long time in ENT and during Independent Era has been programmed as a main and staple food for majority people in ENT. Unfortunately, those program have not supported with the profound program to lift the role of maize for at least similar with the rice program. Indeed, maize programs in some cases have deteriorated maize program and in the same time have shifted food consumption pattern of local people in rural areas.

For almost 10 years previous provincial government claimed East Nusa Tenggara (ENT) Province as "maize province". Bureau Statistical data noticed that there were slightly increases in terms of maize production although it was still not enough to meet

\footnotetext{
* Corresponding author: yohanisngongo@gmail.com
} 
local demand of maize. ENT produces maize around 500,000 tons to close 700,000 tons during 1996 - $2015[1,2]$. High maize price in local market across Timor indicated that maize supply for local market is lower compare to the demand.

Fast increase of human population, limited arable land, development of estate crops and unpredictable global climate change have contributed to the volatile of maize production in ENT and also contributed to frequent food shortage in some areas. Indeed, in planting area of rainy season of 2019/2019 majority farmers in flatland around Kupang District was not able to plant crops particularly rice due to not enough rainfall.

Maize is a main staple food majority of people in rural areas, particularly in Timor Island, Eastern part of Flores Island and Alor Island. People in those Islands simply produce maize mainly for food security, and only slightly for market if there is over production.

Aware that maize is suitable for wide range of micro climate of semi-arid areas in ENT, present provincial Government have launched a program so-called: "maize planting, cattle harvesting or MPCH" The main idea of the program is encouraging farmer to plant maize in agribusiness scale (minimum 1 ha per household) by applying suitable and best practices of agricultural innovation to produce high production of maize both to meet household consumption and over production for selling it to buy cattle. Maize as staple food and cattle (livestock) is symbol of "dignity" of famers in rural areas. Maize should be a "superior" staple for people in semi-arid areas and in the same time should be commercial commodity to improve welfare of majority people who works in the supply chain of maize business.

The paper elaborates new approach in managing maize farming in ENT so called MPHC. This approach actually originated from the collaborative research between Local Government (Agricultural Office of ENT), East Nusa Tenggara -Assessment Institute for Agriculture Technology (ENT-AIAT) and ACIAR. The result of research was incorporated rolled-out by Governor of ENT under management of LGUs Agriculture Office of ENT.

The paper aims to examine East Nusa Tenggara (ENT) Provincial Government programs so-called "Maize Planting, Cattle Harvest" or MPCH that wanted to increase maize production and to reform maize production orientation from traditional/subsistence to commercial. The paper consists of seven main sections. Section one Introduction, section two elaborate methodologies applied in the research. Section three elaborates socioeconomic characteristics of farmers and maize farming in 7 Districts involved in the program. Section Four discusses maize in farming system context. Section Five elaborates transforming maize production in ENT from traditional orientation into commercial orientation and challenging encountered. Sixth section discus Maize Production: Between MPCH vs. Existing that analyses prospects of the program to meet local demand (local market) and in the same maintain inter-island trade to minimize national dependent of foreign imported maize. The last section Seven is a conclusion and recommendation drawn from previous sections.

\section{Methodology}

Data and information used of this study have mainly taken from the on-going program of "Maize Planting, Cattle Harvest or MPCH". The program initiated by Governor of ENT designed and executed under Provincial Agricultural and Food Resilience Office management. Staff recruitment to assists farmers in technical aspects held in August 2019, while participants farmers/stakeholders and land consolidation for maize farming started in September 2019 and maize planting started on October 2019 - February 2020 (depending of Rainfall for each District/village). The program started 2020 in 7 Districts of Timor and Sumba Island. 
Primary data for the paper heavily rely from data collection by trained recruitments staffs (technical assistance) across villages in Timor and Sumba. Field notes shared by experts involved in the program have also used to enrich the narratives. Secondary data were collected from the Provincial Agricultural and Food Resilience Office management involved in the TJPS program, Statistical Bureau of Districts and Provincial Level.

In order to understand farmers orientation involving in TJPS particularly in marketing orientation, recruited assistance purposively determined at least 5 farmers who were fully applied recommendation innovation and therefore had productivity around 5 ton/ha and then analyzed the willingness of the farmers to re-invest of the maize product to buy cattle (Ongole in Sumba and Bali Cattle in Timor.) for comparative analysis across Districts. Most data analyzed descriptively.

\section{Results and Discussions}

\subsection{Socio-Economic Characteristics of Farmers and Maize Farming}

In the first year implementation of the program, it started in 7 Districts of Timor and Sumba Island. Majority farmers in Kupang TTS and TTU Districts consists of Meto ethnic groups which maize as staple food. Belu and Malaka districts consists of Tetun Ethnic group. East Sumba dominated Kambera ethnic group, while in SBD by Wewewa in Midland and Kodi ethnic group in the lowland.

These tribes in general have quite different orientation in Maize production. As the maize is the second important staple after rice, farmers in Sumba and Malaka sub-districts have market orientation more for maize product compare with Meto and Belu which maize is the main staple food. Since the maize market available, almost $80 \%$ of the maize product from farmers in Sumba and Malaka sold, while in others only 25\% - 50\% from the total product.

Aside from the Malaka farmers which have quite different maize farming environment, other districts in general have quite similar maize farming environment. In Malaka, maize farming mostly in the low and flatland areas and the farming land can be farmed twice a year due to the area have bi-modal rainfall pattern. Outside Malaka, maize farmland is mostly in the slopes area and farmed only once a year.

Baseline data showed that before the program, average size of maize farming in ENT was 0.5 ha/household (range $0.25-1 \mathrm{ha}$ ). The lowest land size for traditional maize farming was in Malaka District (0.30 ha), while the highest size in TTS district (1.2 5 ha). Nevertheless, most farmers in Malaka do farming maize twice a year, during rainy season and during dry season without irrigation or so-called Ahuklean or deep planting.

Land ownership of farmers is the highest in East Sumba, while the lowest is in Malaka District. However, almost all household have only able to cultivate average 0.5 ha for maize in mixed cropping system. Maize farms in monoculture system have only practiced in small number of farmers during dry season that have enough water to irrigate. Farmers in Kupang district that close to the market in Kupang town has normally planted monoculture sticky maize or sweet corn for young consumption.

Although farmland for maize is the highest in TTS district, the maize productivity is the lowest (Table 1). As the maize is the main staple food, farmers in TTS face frequent food (maize) deficit. Farming in this district has also experiencing harvest failure due to low and uncertain rainfall particularly farmland along southern coastal lines. By this harsh environment, farmers in TTS and Timor in general have more than one parcel of cultivated lands and practiced mixed cropping systems with the main purpose to minimize risks. 
By different in terms of land size and planting intensity that mostly dictated by rainfall, maize productivity and production among farmers were highly differed. Districts Statistical Data (2016) from 7 Districts showed that the highest maize productivity was 3' 6 ton/ha in SBD District and the lowest in South Central Timor (1.2 ton/ha) (Table 1.).

Table 1. Major ethnic groups, Market orientation, land ownership and maize productivity in 7 districts.

\begin{tabular}{|c|c|c|c|c|c|c|}
\hline \multirow[t]{2}{*}{ District } & \multirow{2}{*}{$\begin{array}{l}\text { Dominant } \\
\text { Ethnic } \\
\text { group/s }\end{array}$} & \multirow{2}{*}{$\begin{array}{l}\text { Dominant } \\
\text { Existing } \\
\text { Market } \\
\text { Orientation }\end{array}$} & \multicolumn{2}{|c|}{ Land (Ha) } & \multirow{2}{*}{$\begin{array}{l}\text { Major } \\
\text { Cropping } \\
\text { pattern }\end{array}$} & \multirow{2}{*}{$\begin{array}{l}\text { Maize } \\
\text { Productivity } \\
\text { (ton/ha) })^{\text {a) }}\end{array}$} \\
\hline & & & Ownership & Cultivated & & \\
\hline Kupang & Meto & $\begin{array}{l}\text { Semi com- } \\
\text { mercial }\end{array}$ & $1-2$ & 1 & $\begin{array}{l}\text { Mixed- } \\
\text { cropping }\end{array}$ & 3.4 \\
\hline $\begin{array}{l}\text { South } \\
\text { Central } \\
\text { Timor/TTS }\end{array}$ & Meto & Subsistent & $1-2$ & 1 & $\begin{array}{l}\text { Mixed- } \\
\text { cropping }\end{array}$ & 1.2 \\
\hline $\begin{array}{l}\text { North } \\
\text { Central } \\
\text { Timor/TTU }\end{array}$ & Meto & Subsistent & $1-2$ & 0.5 & $\begin{array}{l}\text { Mixed- } \\
\text { cropping }\end{array}$ & 2.1 \\
\hline Belu & Tetun & Subsistent & $1-2$ & 0.5 & $\begin{array}{l}\text { Mixed- } \\
\text { cropping }\end{array}$ & 2.8 \\
\hline Malaka & Tetun & $\begin{array}{l}\text { Semi com- } \\
\text { mercial }\end{array}$ & $0.5-1$ & 0.35 & Monoculture & 2.4 \\
\hline East Sumba & Kambera & Subsistent & $1-5$ & 0.5 & $\begin{array}{l}\text { Mixed- } \\
\text { cropping }\end{array}$ & 3.5 \\
\hline $\begin{array}{l}\text { Southwest } \\
\text { Sumba/SBD }\end{array}$ & $\begin{array}{l}\text { Wewewa, } \\
\text { Kodi }\end{array}$ & $\begin{array}{l}\text { Semi com- } \\
\text { mercial }\end{array}$ & $1-2$ & 0.5 & $\begin{array}{l}\text { Mixed- } \\
\text { cropping }\end{array}$ & 3.6 \\
\hline
\end{tabular}

Notes: a). Kupang [2], TTS [3], TTU [4], Belu [5], Malaka [6], East Sumba [7]and SBD [8] Districts in Figures 2016.

Traditional maize farming performance during 2019/2020 planting season across 7 districts has greatly diversed from failure to harvest or too late planting in coastal areas of Timor and Sumba Island until early planting and good harvest in midland of Sumba Island. This circumstance is very much dictated by rainfall pattern in every district.

\subsection{Maize in Farming System Context}

Maize is one of the important food commodities in traditional upland farming and it is main component in integrated farming system. By-product of maize (biomass) is main source of cattle feed. Traditional crops-livestock system (CLS) actually has long been practiced by local farmers in Timor. There is a synergism in every parts of the sub-system. It is common practice for local people in semi-arid areas to plant different kinds of crops and raises livestock to minimize risks, minimize or without external input use and improve nutrients cycling $[9,10,11]$.

Food commodities being planted reflects diet system of society. Maize planted in mixed cropping system particularly with pumpkin and beans. Depend on agro-ecological and farmers' preference, some food crops in small percentage cultivated such as cassava, sweet potatoes and some Diascorea Sp. Indeed, horticultural crops and root crops such sweet potatoes and taro is planted in high percentage of cultivated land in the highland. These crops are the main source of cash income in highland and as a strategy to overcome the food shortage (maize) in the highland.

Livestock commonly raised by farmers as important part in CLS is cattle, pigs, goat and chicken. Cattle for rural farmers is more for saving/cash income, pigs for economic and 
social purposes, goat is more for cash income, and chicken is more for household consumption. During dry season with limited source of cash income, livestock play important roles as main source of cash income, meat/animal protein and for ploughing (Ongole cattle in Sumba).

Most farmers in Timor Island prefer white seed maize for household consumption and they still keeps local early mature maize (yellow). Almost similar with Hellin et al. [9]' finding in Mexico, despite the advantages of introduced HYVs of maize, farmers are continuing to grow local varieties. The main reason for white maize is good taste, and the main reason for keeping early mature maize is that farmers harvest earlier that normally coincide with famine seasons. Some farmers plants old HYVs maize like Kalingga and Arjuna varieties. Small number of farmers plant hybrid maize for commercial purposes or if they received government program support (seed, chemical fertilizer). For HYVs, beside high production, farmers prefer maize with high tolerance to drought.

As the rainfall pattern is quite variable among regions across and within the district, planting calendar and cropping pattern are also quite variable. Nevertheless, most farmers start planting maize in the first chance soon after the rainy season starts. Farmers or region in the relatively high or midland is normally plant earlier that farmers in the lowland or coastal areas (Table 2). Farmers in Malaka districts and in midland of SBD districts do planting maize twice a year due to bi-modal rainfall pattern in Malaka and relatively longer rainfall in midland of SBD district (Wewewa region).

Table 2. Maize farming calendar in 7 Districts of MPCH Program

\begin{tabular}{|l|l|l|l|}
\hline District & \multicolumn{1}{|c|}{$\begin{array}{c}\text { Altitude } \\
(\mathbf{m} \text { asl })\end{array}$} & $\begin{array}{l}\text { Normal maize planting } \\
\text { calendar }\end{array}$ & Dominant Cropping Patter \\
\hline Kupang & $100-300$ & December/January & Maize + pumpkin + beans \\
\hline $\begin{array}{l}\text { South Central } \\
\text { Timor/TTS }\end{array}$ & $\begin{array}{l}50-100 \\
500-700\end{array}$ & $\begin{array}{l}\text { December/January } \\
\text { December/January }\end{array}$ & $\begin{array}{l}\text { Maize + pumpkin + beans } \\
\text { Maize + pumpkin + beans }\end{array}$ \\
\hline $\begin{array}{l}\text { North Central } \\
\text { Timor/TTU }\end{array}$ & $300-500$ & November/December & Maize + pumpkin + beans \\
\hline Belu & $300-500$ & November/December & Maize + pumpkin + beans \\
\hline Malaka & $50-500$ & $\bullet \begin{array}{l}\text { January/February } \\
\text { May/June }\end{array}$ & $\begin{array}{l}\text { Maize + pumpkin + beans } \\
\text { Maize + moonbeam }\end{array}$ \\
\hline East Sumba & $400-700$ & November/January & Maize + Upland rice + cassava \\
\hline $\begin{array}{l}\text { Southwest } \\
\text { Sumba/SBD }\end{array}$ & $\bullet 50-100$ & $\begin{array}{l}\bullet \text { January/February } \\
\text { O Oct./November }\end{array}$ & $\begin{array}{l}\text { Upland rice + Maize }+ \\
\text { cassava } \\
\text { Maize + upland rice }+ \\
\text { cassava + taro }- \text { Maize }\end{array}$ \\
\hline
\end{tabular}

\subsection{Transforming Maize Production Orientation}

Based on the Regional Medium Term Development Planning (RMTDP) of ENT province 2018-2023, agricultural development should enhancing productivity and competitiveness of agricultural products[10]. Therefore, agricultural products should be designed in such a way for commercial purposes. Maize is one of the important commodities that suitable for semi-arid areas in ENT should be developed beyond staple or subsistence level to improve farmers' income.

Although previous Provincial government of ENT was proposing "maize province" program, maize production in ENT was still limited for household self-sufficient. Maize production in the last ten years ranged $550,000-685,000$ ton. As the most of maize production allocated for self-sufficient, only small amount of maize product entered to the local market. Indeed, maize deficit received from the inter-island trade from Surabaya and Makassar. 
Almost all maize farming in ENT is considered as traditional maize farming for subsistence. Only small portion of maize farming devoted for commercial purpose, particularly farmland close to the market in Kupang town. Although majority of upland farmers plants maize, ENT has never experience self-sufficient. Farmers were only supply local market during harvest season on March - May and the rest supplied from other Province.

Poor infrastructure, traditional and small-scale maize farming and limited market for maize have contributed to the high price of maize in local market and therefore it is not competitive as the imported maize. Previous government program on maize is more on farming level or how to increase maize production/productivity with less taken into consideration with other chains in maize business. Within this circumstances and ignoring other supply chains have contributed to the uncompetitive maize product even in the local market and therefore farmers unwilling adopt new innovations to improve maize production.

Aware the importance of the maize as staple for majority of the farmers in semi-arid areas and in the same time the will to improve income of small farmers, present Provincial Government eager to transform maize farming from traditional and subsistence orientation into market or commercial orientation. It started from MPCH jargon. The main idea of $\mathrm{MPCH}$ is any agricultural developments innovations should coming from or created from the farmers' circumstances reality. In the context of semi-arid farmers in ENT, maize and livestock (particularly cattle) is interlinks and supporting business in traditional farming system.

MPCH originated actually from the collaboration study between ACIAR and AIATENT in 2008 that concern on Corn-cattle system in East Nusa Tenggara [11]. [11] revealed that very limited improved maize innovation being adopted by the farmers due to "the farmers are trapped in a downward spiral of dependency" (p.69). The slogan of MPCH proposed in order that farmers could improve maize production realistically for family consumption and still have excess production for cash income that permits them to buy and own cattle. Farmers involved in the study "provided very positive feedback about the process and initial outcomes, but were also able to outline areas for improvement" (p.70).

Table 3. Major changes towards business orientation maize based.

\begin{tabular}{|l|l|l|}
\hline Level & Before & Present/On-going \\
\hline Upland farmers & $\begin{array}{l}\text { - Maize limited for subsistence } \\
\text { - Cultivated land: } \leq 0.5 \text { ha } \\
\text { Traditional practices }\end{array}$ & $\begin{array}{l}\text { Both for food and cash income. } \\
\text { - Minimum cultivated land: 1 ha. } \\
\text { - Implement good agricultural } \\
\text { practices }\end{array}$ \\
\hline Bureaucrats & $\begin{array}{l}\text { Business as usual } \\
\text { Bias sectoral approach/Focus on } \\
\text { technical aspects }\end{array}$ & $\begin{array}{l}\text { - Business oriented } \\
\text { - Integrated/holistic approach } \\
\text { - Mediating roles }\end{array}$ \\
\hline $\begin{array}{l}\text { Private sectors/ } \\
\text { Corporation }\end{array}$ & $\begin{array}{l}\text { Ignoring to invest in food crops } \\
\text { - Investing in food crops (maize). } \\
\text { Gediating market/Off-taker } \\
\text { Exploring to invest in feed } \\
\text { industry }\end{array}$ \\
\hline Government & Bias to central government policy & $\begin{array}{l}\text { - Focus on upland agriculture } \\
\text { Business oriented program to } \\
\text { improve income and welfare. }\end{array}$ \\
\hline
\end{tabular}

After more than 10 years MPCH commenced, present Provincial Government (PG) is adopting the idea of MPCH that hopefully revolutionizing maize farming and upland agriculture in semi-arid in general. It is aware from the beginning that Pilot Roll-out Project (PRO) of MPCH will face some adjustments and constraints when it conveyed into Provincial Program. Nevertheless, implementation of the program so far has positive 
impacts at least for several levels: farmers, bureaucrats, private sector/corporate and Government/regional economy (Table 3) as elaborated below.

For the first time maize farmers involved in the program plants maize in the land area of 1 ha per household from only 0.5 ha or less of traditional practice. By implementing good practice recommendations of maize farming (e.g.: cropping pattern, HYVs, fertiliser, reduce seed, herbicide/weed control, integrated pest management/IPM, post-harvest handling and marketing), farmers have benefitted with the outcomes of maize farming by producing yield $4-7$ ton/ha which they had never experienced in the previous traditional practices. Farmers keep yield $350 \mathrm{~kg}-1000 \mathrm{~kg}$ for household consumption and the rest 3 6 tons sold for cash income. Until June 2010, some farmers were able to purchase and own cattle. Better access to the cattle market in Kupang District allowed half of the involved farmers were able to buy cattle.

In their study of factors that influence household economic decisions of corn farmers in Tesbatan and Camplong II villages of West Timor, [12] showed that the policy to increase the price of corn and expansion maize farming area were very effective to increase household income and consumption of corn. Similar with [12, 13] showed that decreased domestic maize price was responded by farmer through reducing maize planted area and fertilizers uses. Maize price in ENT during good harvest season is less than IDR 3,000/kg, while during close to planting season November - December can reach IDR 5,000 - IDR $8,000 / \mathrm{kg}$. By the contract price of IDR $3,200 / \mathrm{kg}$ and available guarantee market, farmers enthusiastic to plant and expand maize farming.

Considering the unfavourable rainfall pattern during 2019/2020 planting season where most Non-MPCH farmers failed to harvest or very low production of maize. By implementing recommended good practices of maize farming, farmers were able to better manage maize farming with less risk of failure and better yield [14] and involved MPHC farmers have enjoy the reasonable yield and outcomes of the program. They have committed to keep adopting introduced recommendation of good practice of maize farming and hopefully it facilitates for expansion of the program and cultivated land $[12,15]$.

For Bureaucratic levels, MPCH program is good forum for real integrated or harmony collaboration among stakeholders directly and indirectly dealing with maize. By collaborative approach rather than sectoral approach, some constraints faced normally before (e.g. input production availability, price, trade barriers, coordination) have been eliminated. The involvement of all related stakeholders since the early stage up to the implementation of the program have indicated that goal of the program could be achieved.

The important tangible outcome that could be seen from the program is in the first time farmers from ENT does inter-island trade of maize to Surabaya as much 4 containers or equal to 120 tons and local traders absorbed 270 tons. This implies also that maize farming or maize product from ENT is competitive enough with similar imported product (maize) $[16,17]$. Contract between farmers and off-taker facilitated by Provincial Food Crops from the beginning of the programs have bind all parties that guarantee market for the maize and encourage farmers to extend their maize farming. Some studies shows that contract farming/farmers obtain better income, facilitate market participation and promote rural development [18-20].

Available market for upland agriculture commodities including maize have contributed to improve rural income and reducing rural poverty. It is also changes the way farmers practicing maize farming or encourage them to adopt good agricultural practice in maize farming [21, 22]. Farmers group participation, involvement in maize market and infrastructure improvements have positive impact for improving rural income [23, 24].

The main asset own by the farmers island (dominant upland). In the preamble speech of the book: Grand Design upland agricultural of ENT, Governor emphasize from the beginning that upland and upland agricultural is big and main assets to be capitalize for 
prosperity of the people of ENT. It is because majority of people working in the upland agriculture and therefore the spirit of economic development should be based on upland agriculture and it should be never wilt[10]. Government have put in place policies to realize those commitments (e.g. budgeting, market guarantee, inputs, and rural infrastructure).

Under the new regime of provincial government, maize is no longer produced for local consumption or self-sufficient but it a based program for transforming traditional agriculture from self-sufficient into commercial purposes. Business oriented maize based program delivered under the Maize Planting Cattle Harvesting or MPCH. The program started from the reality of most rural farmers that should plant maize as staple and should own livestock (cattle) as saving and source of cash income. By delivering the MPCH, government wanted to return farmers "dignity," as an entry point toward practicing Integrated Farming System (IFS).

Based on the good achievement of the program, provincial government have extended the scale of the program in 2020 dry season that covered an area of 10,000 ha in 13 districts. This provincial initiative program is fully supported by central government (Ministry of Agriculture) by allocating inputs/resources needed (e.g. tractors, hybrid seeds, machine/water pumps, fertilizers).

\subsection{Maize Production: Between Existing vs MPCH}

The distribution of maize planting area in ENT reflects the level of importance of maize among people in different Islands wa indicated by [1]. Maize is a staple food in Timor, Eastern part of Flores Island, Lembata and Alor. However, it is second important food crops in Sumba and Western part of Flores.

ENT Statistical Bureau [25] showed that up to the 2015 the highest maize production was in TTS district (182,000 tons and then followed SBD (62,000 tons), Malaka (58,000 tons) and TTU (56,000 tons). This figures is very much related with maize cultivated area, however maize productivity is still low $(1.5-2.0$ ton/ha). Table 4 shows that during $1992-$ 2015 there was no significant improvement in terms of maize production and productivity in ENT.

There is no indication of improving maize production if it just simply running maize program as business as usual. Lesson learnt from the "maize province" implemented during previous provincial government indicated that there was lack of coordination among stakeholders and institutions dealing with maize farming and farmers trapped in sufficient market.

Dealing with maize through MPCH program offers a strategically different approach. The first place, MPCH program should strengthen the capacity of farmers to meet the level of subsistence (food security) and in the same time farmers have significant excess yield to be sold (maize as source of cash income). Since the beginning, the Food Crops Office is mediating with investor/off-taker and producers (farmers) so that excess maize production can be guarantee to be sold with fair price.

"Cattle Harvest" is more a way of communication strategy to confirm farmers that maize farming profitable enough in short period of time (4 month) if they manage well their maize farming. It is hoped that farmers can buy and own cattle as important part of Croplivestock system. Farmers can also manage the income from the maize being sold for other productive/prospective business - depend on farmers preference and urgently under assistance of extension workers. 
Table 4. Total Area, Total Production and Maize Productivity 1992 - 2015

\begin{tabular}{|c|c|c|c|}
\hline \multirow{2}{*}{ Year } & Total Area & Total Production & \multirow{2}{*}{$\begin{array}{c}\text { Productivity } \\
\text { (ton/ha) }\end{array}$} \\
\hline & (ha) & (Ton) & \\
\hline 1992 & 212,211 & 376,569 & 1.77 \\
\hline 1993 & 206,058 & 366,347 & 1.78 \\
\hline 1994 & 241,965 & 423,416 & 1.75 \\
\hline 1995 & 254,126 & 416,273 & 1.64 \\
\hline 1996 & 252,808 & 551,855 & 2.18 \\
\hline 1997 & 250,460 & 557,457 & 2.23 \\
\hline 1998 & 231,981 & 483,793 & 2.08 \\
\hline 1999 & 237,583 & 493,535 & 2.07 \\
\hline 2000 & 253,224 & 527,230 & 2.08 \\
\hline 2001 & 258,782 & 553,298 & 2.13 \\
\hline 2002 & 258,460 & 580,900 & 2.24 \\
\hline 2003 & 257,724 & 583,355 & 2.26 \\
\hline 2004 & 264,907 & 622,811 & 2.35 \\
\hline 2005 & 239,588 & 552,439 & 2.31 \\
\hline 2006 & 252,410 & 582,964 & 2.31 \\
\hline 2007 & 217,478 & 514,360 & 2.37 \\
\hline 2008 & 270,717 & 673,002 & 2.49 \\
\hline 2009 & 250,536 & 638,889 & 2.55 \\
\hline 2010 & 244,583 & 653,621 & 2.67 \\
\hline 2011 & 246,893 & 524,638 & 2.12 \\
\hline 2012 & 245,323 & 629,386 & 2.56 \\
\hline 2013 & 270,394 & 707,643 & 2.61 \\
\hline 2014 & 257,025 & 647,108 & 2.51 \\
\hline 2015 & 273,194 & 685,081 & 2.51 \\
\hline Average & 246,627 & 556,082 & 2.23 \\
\hline
\end{tabular}

First year of MPCH program in 2019/2020 has started 70 villages distributed into 7 Districts. The program covered 2400 ha or around 2400 farmers. Despite, low and erratic rainy pattern during rainy season $2019 / 2020$, the result of the program is considered success with maize productivity ranged $3.7-6.0$ ton/ha. Depend on rainy pattern, farmers in SBD District does first harvest.

Under the MPCH program, maize productivity ranges $4.3-7.6$ ton/ha (Table 5). This achievement was far enough with the average traditional practices which indeed some farmers fail to harvest. One group of farmers in TTU sold maize 8.4 ton with production sold ranged from $100 \mathrm{~kg}$ to $1700 \mathrm{~kg}$ per farmers. Most farmers in SBD district informed that during the harvest season 2020 they were able to sold maize in significant amount (1 2 tons/ha) which never experienced before. Before the program they just sell maize $50-$ $125 \mathrm{~kg}$ in one season in the nearest local market. They also dealing and enjoy with new market approach where they can sell the maize in their home.

Table 5 indicated that good agricultural practices of Maize and market guarantee have encouraged farmers to better manage their maize farming. Maize productivity achieved more than double with provincial maize productivity indicated that there is potential to increase maize production in ENT and inter-island maize trade. 
Table 5. Number of beneficiaries, maize productivity, production and maize sold in 7 Districts.

\begin{tabular}{|l|c|c|c|c|}
\hline \multicolumn{1}{|c|}{ District } & $\begin{array}{c}\text { No. Farmers } \\
\text { involved (HH) }\end{array}$ & $\begin{array}{c}\text { Average } \\
\text { Productivity } \\
\text { (ton/ha) }\end{array}$ & $\begin{array}{c}\text { Total Production } \\
\text { (Ton) }\end{array}$ & $\begin{array}{c}\text { Average Maize } \\
\text { sold/hh (kg) }\end{array}$ \\
\hline Kupang & 350 & $\begin{array}{c}5.3 \\
(4.3-7.6)\end{array}$ & 1484 & $\begin{array}{c}863 \\
(183-2609)\end{array}$ \\
\hline TTS & 350 & $\begin{array}{c}3.5 \\
(0.5-6.5)\end{array}$ & 1225 & $\begin{array}{c}1200 \\
(200-4000)\end{array}$ \\
\hline TTU & 350 & 2 & 700 & $\begin{array}{c}1500 \\
(100-2500)\end{array}$ \\
\hline Belu & 325 & $\begin{array}{c}2 \\
(0.1-3.5)\end{array}$ & 650 & $\begin{array}{c}750 \\
(100-1000)\end{array}$ \\
\hline Malaka & 325 & $\begin{array}{c}5 \\
(0.7-6)\end{array}$ & 1625 & $\begin{array}{c}2000 \\
(100-3500)\end{array}$ \\
\hline East Sumba & 350 & 4.5 & 1575 & 1500 \\
$(1.2-5.5)$ & 4.76 & 952 & $(1,000-2500)$ \\
\hline SBD & 350 & & 8,211 & \\
\hline Total & 2,400 & & & \\
\hline
\end{tabular}

Source: Tabulated Data

Notes: Number in parentheses is range

Maize is also a major raw material for feed industry. Increasing human population, rising income and changing dietary requirements will increase the demand of maize [26, 27]. Expansion of the program in coming years with keeping or increasing the present achievement will definitely increasing the maize supply and offers opportunity to develop feed industry in ENT.

\section{Conclusions and recommendations}

Despite government efforts to increase maize production and food sufficiency, people in ENT still face food shortage, including maize as staple. Insufficient maize supply reflected in the high price of maize in local market and cannot compete with imported maize.

Improving maize production can be addressed by implementing good farming practices of maize based on farmers' circumstances. Maize production should be meet household food sufficiency and there should be significant excess production to be sold for cash income. The main idea of MPCH is any agricultural developments innovations should coming from or created from the farmers' circumstances reality. In the context of semi-arid farmers in ENT, maize and livestock (particularly cattle) is interlinks and supporting business in traditional farming system.

Under the MPCH program, maize productivity ranges $4.3-7.6$ ton/ha that far enough with the average traditional practices. Farmers have surplus of maize that sold at least 1 ton/ha per household with contract price IDR 3,200 kg and allow farmers to purchase and own cattle. Maize productivity achieved more than double with provincial maize productivity indicated that there is potential to increase maize production in ENT and interisland maize trade.

Market guarantee and government supports to minimize input cost have enable farmers to adopt innovations being introduced through MPCH program. Technical assistance to the farmers to better apply good maize farming practices has also contributed to significant increase of maize yield. Farmers' involvement from the beginning of the program and working with good harmony with related stakeholders have lead to change maize farming orientation from focus to subsistence level to become business/commercial orientation. 
Expansion of the program in coming years needs to be considering key learning experiences from all involved stakeholders. Every (New) District included in the program has specific characteristics that need to be taken into consideration with some adjustments. Beside input production availability (quantity and timely), market capacity to accommodate output production should be readily available.

Acknowledgement. First of all we would like to thanks to Governor of East Nusa Tenggara for launching and supporting the MPCH Program. We are very respect and thanks to all MPCH technicians for collecting and providing field data and information. We also thanks to supporting team at Provincial Food and Estates Crops Office and experts of MPCH actively in WA groups for sharing your views and valuable comments. Any remaining errors are authors' responsibility.

\section{References}

1. Ngongo Y. Ignas. K.L. Bora C.Y. Cramb R.R. Proceeding International Maize Conference. (2012).

2. Kupang District Statistical Bureau, Kupang Dalam Angka 2016 (2016)

3. TTS Statistical Bureau, TTS Dalam Angka 2016. (2016)

4. TTU Statistical Bureau, TTU Dalam Angka 2016 (2016)

5. Belu Statistical Bureau, Belu Dalam Angka 2016 (2016)

6. Malaka Statistical Burau, Malaka Dalam Angka 2016 (2016)

7. East Sumba Statistical Bureau. Sumba Timur Dalam Angka 2016, (2016)

8. SBD Statistical Bureau, Sumba Barat Daya (SBD) Dalam Angka 2016. (2016)

9. J. Ryschawy, N. Choisis, N., J. P. Choisis, A. Joannon, A. Gibon, Animal, 6, 17221730. (2012)

10. Weindl, H. Lotze-Campen, A. Popp, C. Müller, P. Havlík, M. Herrero, et al., Env.l Research Letters, 10 (2015)

11. M. Moraine, M. Duru, O. Therond, Renewable Agriculture and Food Systems, 32, 4356 (2017)

12. J. Hellin, A. Keleman, M. Bellon, Gender and Development, 18, 427-437 (2010)

13. Dinas Pertanian Provinsi NTT. Grand Design Permbangunan Pertanian Lahan Kering Nusa TenggaraTimur. (2018)

14. S. Leki, N. Hanani, R. Dwiastuti, B. Setiawan, Current Agriculture Research Journal, 4, 74-83 (2016)

15. S. J. K. Umboh, D. B. Hakim, B. M. Sinaga, I. K. Kariyasa, Media Peternakan, 37, 198-205 (2014)

16. D.N. Mubiru, J. Namakula, J. Lwasa, G.A. Otim, J. Kashagama, M. Nakafeero, et al., Sustainability (Switzerland) 9 (2017)

17. D. Jiméneza, S. Delercea, H. Doradoa, J. Cocka, L.A. Muñoza, A. Agamez, et al.. Global Food Security, 23, 256-266. (2019)

18. S.M. Wokabi, Kenya Agricultural Research Institute, Nairobi, Kenya, 5 (2013)

19. M.Nassirou Ba, Agricultural Sciences, 8, 1372-1401 (2017)

20. G. K. Abebe, J. Bijman, R. Kemp, O. Omta, A. Tsegaye. Food Policy40, 14-24 (2013)

21. I.B. Lambrecht, C. Ragasa, Food Policy 74, 9 - 22 (2018).

22. E.M. Meemken, M.F. Bellemare, Proceedings of the National Academy of Sciences of the United States of America, 117, 259-264. (2020).

23. A.Keil, C. Saint-Macary, M. Zeller, Quarterly J. of International Agriculture, 52, 1-25 (2013).

24. Mitiku, The International J. of Applied Economics and Finance, 8, 51-61. (2014).

25. F. E. Mmbando, E. Z. Wale, L. J. S. Baiyegunhi, Food Security (2015)

26. NTT Statistical Bureau, NTT in Figures 2018 (2018) 
27. M. Tigchelaar, D. S. Battisti, R. L. Naylor, D. K. Ray, Proceedings of the National Academy of Sciences of the United States of America, 115, 6644-6649 (2018)

28. J. M. Pasuquin, M. F. Pampolino, C. Witt, A. Dobermann, T. Oberthür, M.J. Fisher, et al., Field Crops Research, 156, 219-230 (2014) 